\title{
超音波風速温度計と赤外線湿度変動計を用いた渦相関法による 乱流輸送量測定の解析法の検討
}

\author{
Considerations on the Eddy Correlation Method Using Sonic \\ Anemometer-Thirmometer and Infrared Hygrometer \\ 玉川一郎 ${ }^{*}$ (名古屋大学大気水圈科学研究所) \\ Ichiro TAMAGAWA Institute for Hydrospheric-Atmospheric Sciences, Nagoya University
}

\begin{abstract}
The effects of corrections for temperature and for humidity are studied in the context of the flux measurement with the eddy correlation method, based on the observed data. Corrections for cross wind and humidity effects to the temperature measured by the sonic anemometer-thermometer, and dynamic calibration and the correction for the low frequency unstability for the humidity measured by the infrared hygrometer are surveyed. The correlations for temperature are needed to avoid systematic overestimate of sensible heat flux. The dynamic calibration for infrared hygrometer is absolutely necessary, now. The correction for the low frequency is important only for the extreme conditions.
\end{abstract}

Key words : Eddy correlation, Correction, Sensible heat, Latent heat

観測されたデー夕を用いて，渦相関法で乱流輸送量を測定する場合の補正の大きさを調べた。ここで調べた補正は, 超音波風速 温度計の温度に対しては, 横風と水蒸気の影響の補正, 赤外線湿度変動計の水蒸気量に対しては, 比較校正 (dynamic calibration) と低周波補正である．超音波風速温度計に対する横風と水蒸気の補正は, 顕熱輸送量の系統的な過大評価を避ける為に必要で, 水 蒸気のdynamic calibrationは現時点ではしなければならない. 低周波の補正は極端な状況でのみ必要である.

キーワード: 渦相関法, 補正, 顕熱, 潜熱

\section{I 、はじめに}

1960年代後半から1970年代にかけて, 超音波風速 計を中心とする各種計測機が開発され，乱流輸送量 の直接観測が行われるようになった．近年GAME をはじめとする各種プロジェクトの実行に伴い，渦 相関法を中心とする乱流輸送量の直接観測が各地で 多く行われている．また，それに伴い乱流観測を行 う研究者も, 以前の接地層乱流を専門とする研究者 から, 熱収支・水収支の一部として乱流輸送量観測 を行う広い範囲の研究者へと広がっていった。

超音波風速計は, 現在では大変安定した計測機で あり，コンピュータも速いサンプリングで得られる 多量のデー夕を容易に処理できるだけの性能を持っ たが，まだ，赤外線湿度変動計などは開発途中の測
定機であり, 得られたデー夕の処理には, 後述の dynamic calibrationなどの処理が必要とされている. また, Kaimal and Finnigan(1994)にあるように, 超音波風速温度計の気温出力にも補正が必要な場合 があり，更に，顕熱について議論したSun et al. (1995)や物質輸送について議論した有名なWebb et $a l$.(1980)のように, 計測される時系列と求めたい乱 流輸送量との関係も，水蒸気による比熱変動や乾燥 大気の質量フラックスなどについて, 注意が必要で ある.

これらの方法は，多くは既に知られ使われている ものであるが，多くの観測デー夕を使ってどれくら いの誤差になるかを示した論文はあまりない。また， この種の話はまとまって紹介されていると実際の使 用に便利でもあることから，特に，超音波によって

\footnotetext{
*名古屋大学大気水圈科学研究所 $\overline{1} 464-8601$ 名古屋市千種区不老町

Institute for Hydrospheric-Atmospheric Sicenses, Nagoya University, Furo-cho, Chikusa-ku, Nagoya 464-8601, Japan
} 
計測された気温，赤外線による水蒸気量の時系列の 処理方法を中心に各種補正を適用した際の効果につ いて観測值を用いて調べ，また，その処理を一連の デー夕処理の手続きとしてまとめる. 特に水蒸気量 の測定に関しては, 水蒸気変動計の低周波補正など 今まで注目されていなかった補正に対する考察も行 う.

\section{II . 計測機とデータ}

本論文で使用された計測機は，国内でもっとも広 く利用されていると思われる超音波風速温度計 Kaijo DAT-300 と赤外線湿度変動計Kaijo AH-300 の組合せである，Kaijoの超音波風速温度計は現在 DA-600となっているが, 同一原理のものである.

風速計の感部は 120 度交差型を使用している. 両者

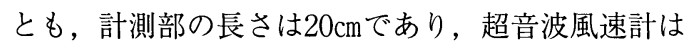
プローブ間を往復する音速差から風速を, 往復の平 均音速から気温を計測し, 赤外線湿度変動計は赤外 線の水蒸気による減衰から水蒸気量を計測する。 以 下で議論する各種補正は同じ原理のセンサーであれ ば同様の議論が可能であると考えられるものである. これらの計測機から得られる，

・風速 3 成分,

・超音波による気温,

·水蒸気量の変動成分,

・標準温度計の気温・相対湿度

を使って, 風速 3 成分, 気温, 水蒸気量の最も妥当 と考えられる時系列を作成し，それを使って，運動 量, 顕熱, 潜熱 (水蒸気) 輸送量を求めるという順序 で，以下の論を進める.

使用するデー夕は, 中華人民共和国の甘肃省で行 われた日中共同観測計画HEIFEの砂漠観測点の 1991年のデータから, 降雨などの問題のある例を省 いた299例(Tamagawa，1996)を主に使用し，水蒸気 に関しては, 浜松市の神原配水場で曇天〜降雨時に 行われたデー夕の内, 問題の無い86例を加えて使用 した. 観測は通常良く行われる10Hzのサンプリン グで，30分の観測を繰り返し行っており, 観測高度

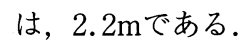

\section{III. 時系列の処理}

\section{1. 風 速}

正しく調整された超音波風速計は, 原理的に風速 の絶対測定であるので測定自身には問題がない.し かし, プローブやその支持具による風の場の変形に
は当然考慮が必要である。

プローブによる風の場の変形については, ATI社 の超音波風速計の場合には, プローブの影響補正の 方法が, 例えばKaimal and Finnigan(1994)にある ように知られているが，ここで扱うKaijoの水平成 分用プローブが120度に開いたものの場合, 正面方 向からの風には影響がない事が分かっているので, 補正は通常しない. 従って風速の測定值としては出 カデー夕そのままで良いことになる。但し, 長期観 測や連続観測の場合は必ずしも良い方向にセンサー を向ける事ができず, 感部のデザインの変更や補正 が必要になるかもしれない. 3 軸直交型の感部に対 しては, 例えば清水 (1998)に補正式の提案がある。

しかし, 観測項目の中で唯一のベクトル量である 風速は, 方向を問題にしなければならない。通常,

「流れは境界面に沿い，流れ方向の物理量の勾配は， 境界面の法線方向の勾配に比べて無視できる」と言 う境界層近似を行い, 水平一様面上での観測では, 水平面上の風向方向に $u$, 鉛直方向に $w$, 残る方向 を右手系でvとするように, 観測された風速成分を 回転する.

観測場所の水平一様性が充分ではない場合は, 観 測結果に比較的大きな平均鉛直風 $(w:$ 以下, 平均值 を一で表す)が得られる。 $w$ と何か物理量 $x$ の積の平 均值から, 鉛直方向の輸送量を求める渦相関法をそ のまま適用すると, $\bar{w} \bar{x}$ 輸送量として扱わねばな らないが，普通それは非現実的な巨大な輸送となる。 この様に計測可能なくらい大きなwは, 地表の起伏 に沿って流れる平均流の成分であり，それによって 流される熱などの物理量は地面に沿って輸送されて いるので, 地表面から大気への輸送量を求めたい場 合に含めるべきではないと考え, 鉛直成分を含めた 平均風方向を $u$ とするように, 上記の座標回転に加 え, 鉛直方向へも座標を回転する事が良く行われて いる(Pond et al., 1971 ; Kaimal and Finnigan, 1994). 境界層近似としては比較的納得できるものではある が,これで求めたものが広域を代表する輸送量に なっているかどうかは明らかではない.

同様の処理をした例として, Tamagawa(1996)の, 幅約 $20 \mathrm{~m}$, 高さ約 $1 \mathrm{~m}$ の砂丘の上での, 高さ $2.2 \mathrm{~m}$ での観測例では, 砂丘の影響を受けて, 全観測の平 均で, 平均鉛直風が平均水平風の $6 / 100$ で吹き上げ ている。ここでの平均鉛直(水平)風とは, 30分間の 各観測での平均の意味である。この場合, $u-w$ 平 面で座標を回転し, 平均の $w$ が 0 になるように座標 
回転した結果, 回転前には, 負のシアー応力がしば しば見られていたのがほとんど無くなり，間接的に この補正の有効性を示している。ただ，顕熱・潜熱 の輸送量では運動量に比べてこの影響は小さい。

この種の複雑地形上での観測については, 今後, 集中的な多点観測を行い調べる必要があると思われ る.

\section{2. 気 温}

Kaijoの超音波風速温度計は, プローブ間の音波 の往復の平均速度を静止大気中での音速と考え, そ こから気温を求める. 従って, 音速から得られる気 温には, 水蒸気の影響と, 測定軸に垂直な風速が影 響を与える。これも, Kaimal and Finnigan(1994) に詳しい. また, 平均気温は誤差が大きい恐れがあ るので使わず変動成分だけを使用するのが通常であ る. 平均の気温には, $\mathrm{AH}-300$ の標準温度計を利用 する事ができる。

気温 $T$ と, 観測される気温 $T_{\text {meax }}$ との関係は, 測定 スパンに垂直な方向の風の成分 $V_{n}$ と, 混合比 $r$ の水 蒸気の影響を考慮して以下のように表される(Kaimal and Finnigan, 1994).

$$
T=\frac{T_{\text {meas }}+\frac{V_{n}^{2}}{A}}{1+0.32 \frac{e}{P}}
$$

ここで, $P, e$ はそれぞれ大気圧, 水蒸気圧であり,

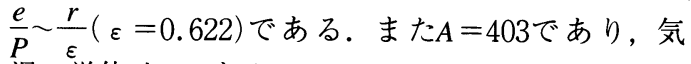
温の単位は $K$ である.

この計算で使われる水蒸気量は, 次節で述べる赤 外線湿度変動計の補正済の観測值であるべきである が, その赤外線湿度変動計の補正にも気温の時系列 が必要なため, 式(1)を分子部分の横風補正と分母部 分の水蒸気補正に分けて, 以下のような手順で近似 的に処理するのが良いと考える。

1. AH-300の標準の温度計を使い, 平均值を合 わせる。

2. DA-600はw成分で温度を計るので, $A, B(u, v)$ 成分の出力から求めた風速計の $w$ 軸に垂直な風 速を使って, 横風の補正をする。

3. $\mathrm{AH}-300$ の標準の温度計を使い, もう一度平 均值を合わせる.

4. 校正後の $\mathrm{AH}-300$ の赤外線からの水蒸気量を 使って, 水蒸気の補正をする.

5. AH-300の標準の温度計を使い, 更にもう一
度平均值を合わせる.

もちろん，白金抵抗線や熱電対を使った温度計の 場合はこのような補正は不要であるが, 充分なレス ポンスを持ち, 鉛直風と同一の場所で測定できる超 音波風速温度計のメリットも大きい.また，上記処 理は線形化して使う事もできる．もち万ん，連立方 程式にして赤外線湿度計の補正と同時に行っても良 い.

上記横風による補正の影響を見るため, HEIFE 砂漠観測点のデータを用いて，水蒸気補正をしない 状態で, 横風補正の前後での気温の標準偏差の違い

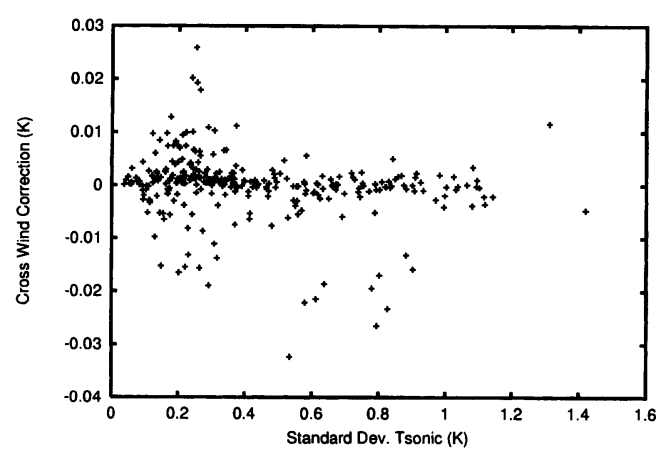

図一1 超音波風速温度計DAT一300で計測された 気温の標準偏差 $\sigma_{T}$ について, 横風補正の 大きさ (Cross Wind Correction $=\sigma_{T}$ (横風補 正後) $-\sigma_{T}$ (横風補正前) ) を, 補正後の值 (Standard Dev. Tsonic $=\sigma_{T}$ (横風補正後)) と比較したもの HEIFEの1991年砂漠観測 点のデータより, データ数は299点で, ここで の気温は水蒸気補正を施す前のものである.

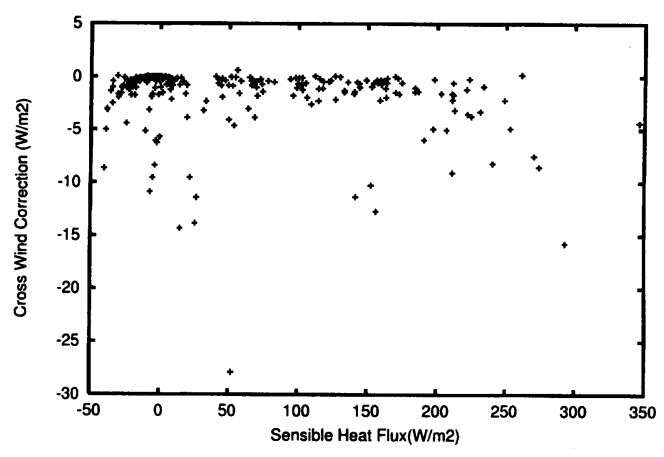

図一2 顕熱フラックスについて, 横風補正の大き さ(Cross Wind Correction)を, 補正後の值 (Sensible Heat Flux)と比べたもの データ は図一 1 と同じ. 
を調べたのが，図ー 1 である，これによると標準偏 差に対する補正の大きさは通常0.01K以下，大きく ても0.04K程度であり，それほど大きなものではな い. 温度变動が大きな場合問題にはならない.

また，同様の比較を顕熱フラックスに対して行っ た場合は，図一2のようになり，補正量は同様に， 通常数 $\mathrm{W} / \mathrm{m}^{2}$ と大きくは無いが, 水平風と鉛直風と の相関が常に負であることから，いつでも，顕熱つ ラックスを小さくする向きに補正される，また，顕 熱フラックスが 0 に近い場合でも補正の大きさが小 さくなったりはしない.このような性質のため, 補 正しないと顕熱フラックスの過大評価になるので, 熱収支の観点からは補正が必要である。

水蒸気による影響は, 標準偏差の場合, 図一 3 に 示されているが, 水蒸気量変動と気温変動が, 変動

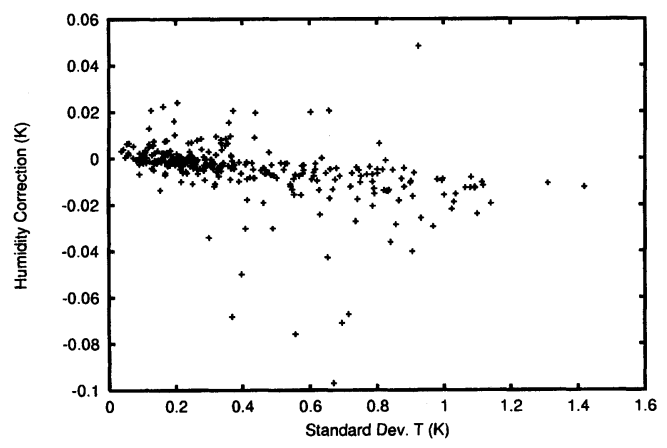

図一３気温の標準偏差について水蒸気補正の大き さ(Humidity Correction)を補正後の值 (Standard Dev. T) と比べたもの データ は図一 1 と同じ.

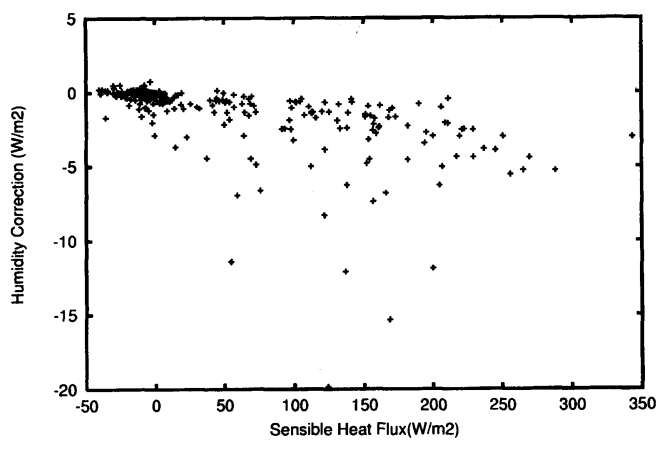

図一4 顕熱フラックスについて水蒸気補正の大き さ (Humidity Correction)を補正後の值 (Sensible Heat Flux)と比べたもの データは 図一 1 と同じ.
の大きい日中に良い相関を示すため，補正の大きさ と気温変動との間に負の相関が見られ，多くの場合 標準偏差を小さくする向きに補正される，系統的な 誤差につながるため, 統計的な扱いをする場合, 補 正は行っておいた方が良いと考えられるが，影響は 小さい.

また，顕熱フラックスに関しては，図一 4 に示さ れているが, 横風とほぼ同じくらいの大きさで, 顕 熱フラックスが大きい時に補正量が大きくなるとい う傾向がある。また，ほとんどの補正は顕熱輸送量 を下げる向きであるので, 横風補正と同様に熱収支 の観点からは補正の必要があると考えられる。

\section{3 . 水蒸気量}

赤外線湿度変動計 AH-300は, Hyson and Hick (1975)で示された方式の水蒸気変動計であり, $q$ と 言う名前で出力されているのは, 赤外線の受光強度 $I$ の変動成分を $I^{\prime}$, 平均成分を $\bar{I}$ とした時の $I^{\prime} / \bar{I}$ に比 例する值で，設定により，10分ないし5 分のハイパ スフィルターが, 変動值 $\left(I^{\prime}\right)$ を算出する為に使われ ている $\left(\bar{I}=I-I^{\prime}\right)$. その出力を水蒸気量に直すため の係数は, 室内実験でメーカーにより校正されてい るが, 野外観測では, レンズの污れや，発光部，受 光部の劣化や, 計測機内部に侵入した水蒸気などの 影響を受けて，変化してしまう。そのため標準とな る安定した水蒸気量の観測值と比較して，両者が良 好な測定のできる周波数帯での変動を比較して, 観 測毎に校正 (dynamic calibration)する必要がある.

このdynamic calibrationは, 1 世代前のモデルで ある機械式チョッパーを用いた $\mathrm{AH}-100 に$ 対しても 使われていた。 $\mathrm{AH}-100$ の当時は, 細い熱電対を 使った乾湿球温度計を利用していたが，レスポンス に余裕があり広いレンジでdynamic calibrationする ことができる反面, 水の供給など湿球観測の維持に 手間がかかる事から，AH-300では容量型の湿度計 に変更されて, 校正用標準計測機として装備される ようになっている。

図一 5 は，無作為に選んた観測值で，標準温湿度 計から得られる水蒸気密度と赤外線センサーで得ら れる水蒸気密度とのコスペクトルをパワースペクト ルで規格化して表示したものである。ほぼ $1 / 30 \mathrm{~Hz}$ 以下に高相関を示す領域が見られるので, 赤外線セ ンサー側のハイパスフィルターの時定数 (5あるい は10分)を考慮し，1/300-1/30Hzの範囲がdynamic calibrationに利用されている. 他の例でも同様の結 


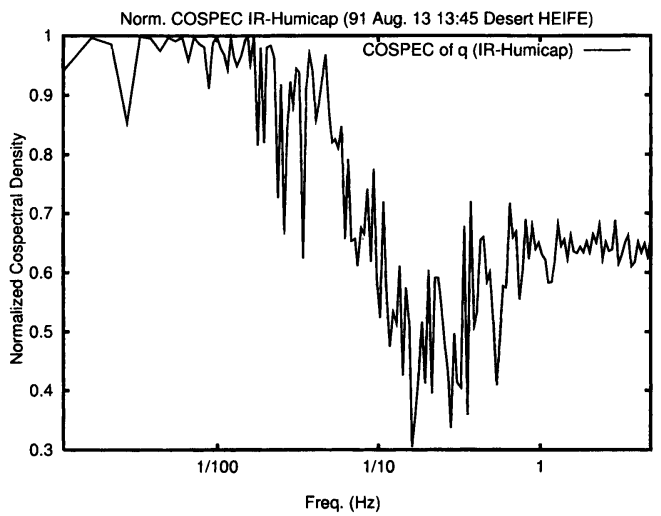

図一 5 赤外線による水蒸気変動の観測值と標準温 湿度計による観測值との比較例 それぞれ 水蒸気密度変動に換算した後, 両者のコスペ クトルを計算しパワースペクトルの平方根で 規格化してある，1/30Hz以下に高相関を示 す領域が見られ，そこが校正に使用できる。

果が得られる. 当然の事であるが, この比較周波数 範囲における実際の現象の水蒸気変動があまり小さ いと誤差が大きく校正にならないことがあり得る. そこで, 比較周波数帯での平均コスペクトルや相関 を同時に調べるなどの処理をする必要がある.

標準温度湿度計に装備されている温度計は, 湿度 計に比べて応答がかなり悪いため, 代わりに応答の 良い超音波風速温度計の温度出力を使えば更に良い 校正になるとも考えられるが，AH-300の初期製品 に対して調べた結果では，実際にはそうならない。

これは, 標準温湿度計に触れる空気はシェルターゃ センサー部のフィルターの熱慣性の影響を大きく受 けているからであると推測されている(玉川, HEIFEプロジェクトのための内部資料，1991）。しかし， dynamic calibrationに使用する周波数帯は広ければ 広い程, 校正係数は統計的に安定し, またその周波 数帯に十分な水蒸気変動のパワーがあり良好な校正 となる可能性も上がるので, 標準温湿度計に対する 今後の改良も望まれる。

このdynamic calibrationは, 現在のAH-300になっ てからでも, Tsukamoto et al.(1995), Mitsuta et al. (1995)，Tamagawa(1996)など良く使用されている.

伊藤 (1998)は, AH-300の校正係数の変化を考察 し, 計測機内部に侵入した水蒸気の影響が主原因で あるとしている. 観測值から, 校正係数が, どのよ うに変動するかを示したのが, 図一6である.ここ で, 校正係数はメーカでの校正係数を何倍すれば正

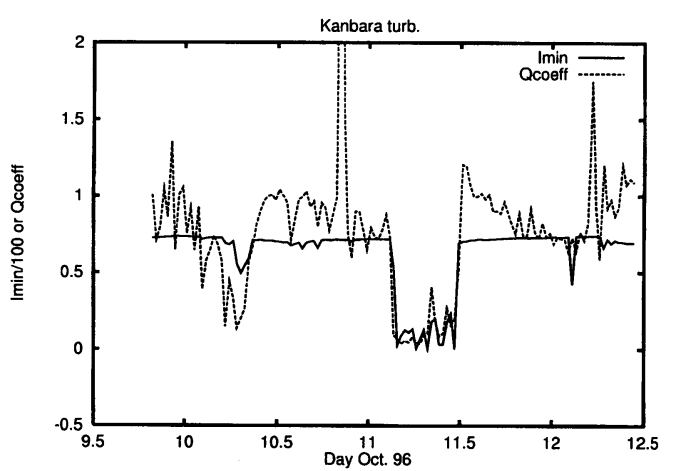

図一6 神原配水場 (浜松市)での暴天〜雨天時の観 測にみる，観測毎の赤外線出力の校正係数 Qcoeffと, 最小受光強度Imin Iminが下 がっているのは, 降雨があったことを示す。 また, Qcoeffは, 1/300-1/30Hzでの, 変動 パワーの比(標準温湿度計/赤外線湿度計)の平 方根であり, 赤外線出力の校正係数になって いる. 約50\%の変動がみられる.

しい值になるかという相対単位で示されている。気 象条件は，晴で時々小雨が降る状況である．雨の影 響は測定パス内, 主に受光レンズ上に雨滴が乗った 時に現れるが, その際, 液体水による赤外線の吸収 により, 受光強度が低下するのでその30分の観測期 間での最低值 (Imin) とともに, 校正係数 (Qcoeff)を 示してある. Iminが少しでも下がっているところ は，降雨の影響を受けていると考えられるので考察 から省くと, 降雨後Qcoeffが, 1.2 程度まで大きく なり時間とともに徐々に下がって 0.7 程度になって 行くのが見られ，センサー内部に侵入した水蒸気の 影響であるという伊藤の考察と整合している.この ようなセンサー内部への水蒸気の侵入は, 他の赤外 線変動計でも見られているようである。レンズの污 れや光学部の経時変化をも考えると, この種の計測 機を野外で使用する場合, 何らかの校正作業が必要 である。

また, AH-300では, 低周波の変動は原理的に測 定できないだけではなく, 実時間処理のため, $I^{\prime} / I$ のフィルターによる時間遅れも生じている. 低周波 変動の水蒸気フラックスへの寄与はあまり大きくな いと考えられるが, 標準温湿度計の観測值があるの でそれを使って補った方が良いと考えられる．図一 7 では, dynamic calibrationして平均值だけ補った データと, 更にそのデータに後述の方法で低周波 (1 $/ 150 \mathrm{~Hz}$ 以下)の変動を標準温湿度計から取り出して 

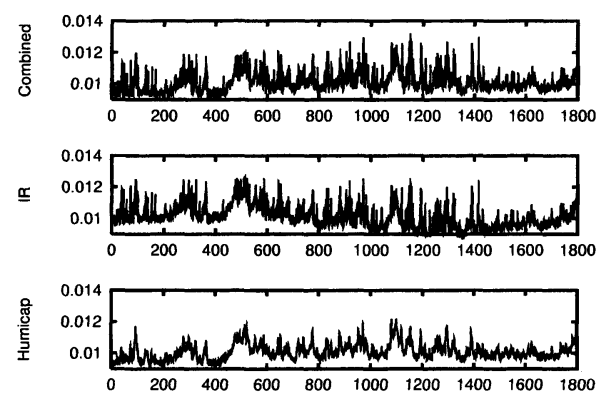

(sec.)

図一7 標準温湿度計による水蒸気混合比(下) と, dynamic calibrationを行った赤外線湿度変 動計の観測值に標準温湿度計から求めた平 均值のみ補った水蒸気混合比(中), 標準温 湿度計の観測值の低周波成分とdynamic calibration後の赤外線湿度変動計の観測值 の高周波成分を合成した時系列(上) 赤外 線湿度変動計 $\mathrm{AH}-300$ は, 速い変動を捉えて いるが, 内蔵されたハイパスフィルターの位 相遅れによると見られる非物理的なゆっくり した変動がみられる。デー夕は, HEIFEでの 砂漠観測点の観測による。この例は, 低周波 数帯の補正で潜熱輸送量が, $167 \mathrm{~W} / \mathrm{m}^{2}$ か ら, $116 \mathrm{~W} / \mathrm{m}^{2 へ}$ と補正される低周波変動の影 響の特別大きいものである.

入れ換えたもの, そして, 標準温湿度計だけから求 めたものとを比較してある.この例では, 赤外線湿 度変動計の出力に, 図で一波程度のゆっくりとした 変動が見られるが, 標準温湿度計では見られず, 非 物理的な変動であることが分かる.このように，赤 外線出力に非物理的な低周波変動が見られる事があ り，一般的に良好な時系列を得るには，低周波成分 は赤外線湿度変動計の観測值を使わず標準温湿度計 の観測值を使う方が良いと考えられる。ここでは, FFTを利用し，フーリエ変換した赤外線湿度变動 計の校正済出力を混合比に直したものの高周波成分 と, 同じくフーリエ変換した標準温湿度計から求め た混合比の定数部まで含めた低周波成分を併せて, 逆フーリエ変換している.この処理を行うと時系列 の最初と最後に影響が出るので, 更に手法の改良が 必要ではあるが，実用上は，適切な測定時間をとっ ていれば, 水蒸気フラックスを含む乱流統計量は 少々の観測時間の延び縮みに対して安定しているの で, 両端のデータをフラックスの計算に用いないと いう処理で通常は充分である.

図一7に見られる非物理的変動の水蒸気フラック

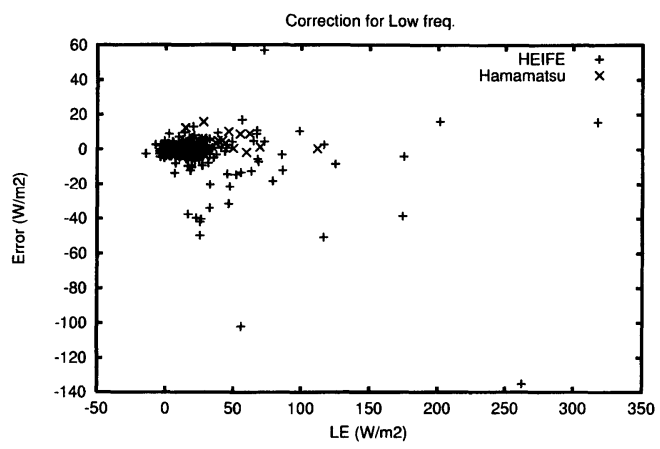

図一8 赤外線湿度計の低周波変動による潜熱輸送 量の誤差. 横軸は潜熱輸送量, 縦軸は低周 波変動を補正しなかった為の誤差 デー夕 は, 1996年の浜松観測 (86例) と, 1991年 の HEIFE砂漠観測点 (299例)．降雨などの影響が ないと考えられる例のみをプロットした。

スへの寄与を見るため，上記補正を行ったものと， 低周波変動も赤外線湿度計の出力を使用したものと の誤差を全てのデータについて描いたのが, 図一8 である、これを見ると，多くのデー夕は誤差10W/ $\mathrm{m}^{2}$ に収まっているが, 䛊差が大きい例も幾つか存 在する、特にHEIFE砂漠観測点には，100W/m 越える誤差を生じている例も少ないながらある。こ の中で, もっとも誤差の大きな点は, 観測時に大変 風が弱く又吹上が大きく, HEIFEの場合に採用し た各観測毎に吹き上げる風に沿わせて座標を回転す る処理での回転角度が特別大きいもので, 水平風に 乗った水蒸気量の変動の影響を受けていると考えら れる特殊な例であるが，そうでない他の例でも移流 などなんらかの原因で低周期変動による水蒸気輸送 が大きく補正が必要な場合がある.

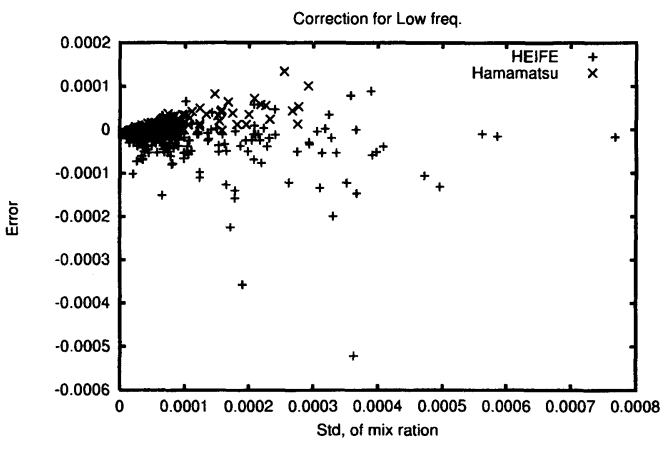

図一9赤外線湿度計の低周波変動による混合比の 標準偏差の誤差 デー夕は, 図ー8に同じ. 
また，混合比の標準偏差は更に影響を受けやすい (図一9)。これは，潜熱が比較的低周波変動の少な いwとの相関で決まるのに対し, 標準偏差は水蒸気 量の変動だけで決まるからである，上述の水蒸気フ ラックスの場合と同様に, HEIFEでの観測值に大 きな誤差を生じている物が多い。誤差の大きさは, 通常, 標準偏差の数分の 1 である.

以上まとめると, 以下の様な処理を施す必要があ る事になる。

・標準センサーの温度湿度出力を使って, 水蒸気 密度を計算する。

・適切な周波数帯 $(30 \mathrm{sec} .-300 \mathrm{sec}$. ) で变動パ ワーの比較により, 校正を行う。

・校正された赤外センサーの出力と, 標準セン サーの水蒸気密度の時系列をのちの利用に備え， 混合比 $r$ に変換する。

・低周波成分は, 標準センサーから求めた $r$, 高 周波成分は校正したIRのrから合成する。(例 えば, FFTして，合成後に逆FFTするなど）

上記処理は, 各観測毎に行う必要があるが, 連続 した観測に対する事後処理には, FFTよりもより 自然に使用できる, 位相遅れの無い周波数フィル ターの使用，あるいは，直交waveletの使用が考え られる，実時間処理は，過去の時系列デー夕のみを 使用してフィルター操作をする必要があるが, 位相 遅れがあるので, 完璧に行うことは不可能である. その意味で, 低周波成分から高周波変動まで正確に 計測する実時間処理は, 赤外線センサーの安定性が

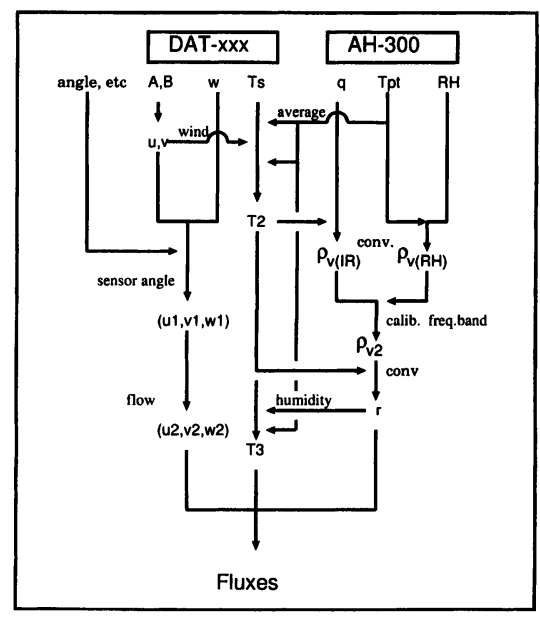

Flow of data processing

図ー10 補正を含めたデータ処理の流れ
十分上がり, Hyson and Hicks夕イプの処理や校正 の必要が無くなるまでは無理であり，レンズの污れ などを考えると光学センサーのみでは難しい.

\section{4. 時系列作成のまとめ}

いままでの節のデータの処理をまとめると, 図一 10のようになる，詳細は，いままでの節にある通り である。

この処理により, 超音波風速温度計と赤外線湿度 変動計によって得られたデータからもっとも確から しい時系列が得られることになる。

\section{IV . 輸送量}

水平一様で定常な場合に, 渦相関法である物理量 $x$ の鉛直輸送量 $F$ を求めるには, 一般に

$$
F=\overline{x w}=\bar{x} \bar{w}+\overline{x^{\prime} w^{\prime}}
$$

を計算すればよい．しかしここで問題がある， $\bar{w} の$ 項である，上述の補正の所でも書いたように，平均 鉛直風は 0 であるかのように扱っているが，実際に は，渦による物質輸送に伴う補償流の影響を考えな ければならない. Webb et al.(1980)によると，大 気を乾燥空気と水蒸気に分けて考え，そのうち地表 面での相変化で生成され観測面を通り抜けてゆく水 蒸気を除いた乾燥空気の質量は, 平均気温の変化に よる熱膨張(収縮) は充分小さいことから，一定でな ければならない，少なくとも，その条件がなりたた ないのなら，移流の存在を考えなければならず，輸 送量の観測值と地表面での輸送量との関係を再検討 する必要がある。

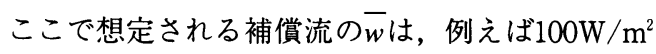
の顕熱の場合で $0.3 \mathrm{~mm} / \mathrm{s}$, 非常に小さく超音波風 速計をもってしても観測はできない，また，現実の 地形などの局所的な影響よりも小さい可能性がある.

フラックスを計算する場合に, 乾燥大気の質量フ ラックスが0であるという仮定を入れるので, 水蒸 気量は, 乾燥大気に対する水蒸気の比である混合比 を使うのが, もっとも式が簡単になり, 水蒸気輸送 量は

$$
E=\overline{\rho_{a}} \overline{w^{\prime} r^{\prime}}
$$

と良い精度で書くことができる，潜熱輸送量に直す 場合は，蒸発の潜熱 $L$ をかける必要があるが，Lに は, 若干の温度依存性があり, 厳密には蒸発の起 こっている地表面の温度の值を使わなければならな いが, その差は小さい.

顕熱の場合は, 水蒸気変動による湿潤大気の比熱 
の変動などもあり, 複雑な議論が必要であるが, Sun et al. 1995によると, 水平一様な場で, 観測高 度と地表面との間でのエネルギー保存と上記Webb et al. に示された乾燥空気の質量保存より, 結局, 通常使われる

$$
\begin{aligned}
H & =\left(C_{p a} \overline{\rho_{a}}+C_{p v} \overline{\rho_{v}}\right) \overline{T^{\prime} w^{\prime}} \\
& =\overline{C_{p}} \bar{\rho} \overline{T^{\prime} w^{\prime}}
\end{aligned}
$$

で，良いことになる， $\overline{C_{p}}, \bar{p}$ は，湿潤空気に対する平 均の定圧比熱，密度である。

但し，顕熱自身が小さい場合には，観測面を通り 抜けて行く水蒸気が持って行くエンタルピーを考慮 する必要がある場合もある，考慮すべきなのは，地 表面からでた水蒸気が観測高度に達するまでに得た， あるいは失ったエンタルピーであるので, エンタル ピーの基準温度は, 地表面温度 $\left(T_{s}\right)$ となり, $C_{p} E$ $\left(\bar{T}-\bar{T}_{s}\right)$ の大きさとなる. 上記Sun et al. によると 極端な場合で $5 \mathrm{~W} / \mathrm{m}^{2}$ 程度とのことである.

運動量も同様に，水蒸気による密度の変動がある が，顕熱に対してSun et al. が示したのと同様に, 通常は,

$$
\gamma=\bar{\rho} \overline{u^{\prime} w^{\prime}}
$$

でよいことになる。水蒸気輸送に伴う運動量輸送は $100 \mathrm{~W} / \mathrm{m}^{2}$ の潜熱で風速 $1 \mathrm{~m} / \mathrm{s}$ の場合で $4 \times 10^{-5} \mathrm{~kg} /$ $\mathrm{m}^{2} \mathrm{~s}$ 程度であるので, 通常無視できる。

\section{V.まとめ}

現時点での標準的な構成のシステムを使って, 標 準的な解析法を示すべく, 渦相関法による乱流輸送 量の計測を行う場合の問題点を調べ, 観測データに よって例を示した。

超音波風速温度計で計測された気温から顕熱つ ラックスを求める場合, 横風と水蒸気の補正はとも に10W/m程度ながら, 系統的な誤差を防ぐ為に必 要である。また，赤外線湿度変動計で潜熱フラック スを求める場合，校正係数に $50 \%$ 程度の影響がある 場合がありdynamic calibrationを行わなければ観測 值にあまり意味は無い. 低周波変動に対する補正は, 通常はあまり大きくないが, 砂漠での観測のような 水蒸気変動の特性が特殊な場合には, 例は少ないな がら大きな誤差をもたらす場合がある。

乱流フラックスの測定を精度良く行うためには, 図一10にまとめた時系列の処理を式 $5,4,3$ の輸 送量の計算に先立ち行う, あるいは, それと数学的 に等価な処理を輸送量算出の際に行う必要がある. これらの処理は, 現在のコンピュータにとっては容
易な処理であり，常にすべて考慮しておくようにソ フトウェアを作成し, 多地点・長期の観測が要求さ れる今後の熱・水収支研究に備えるのが良いと考え る.また，そのためには常に，3次元の風速・気温 ・水蒸気量をセットにして測定することが大切であ る.

謝辞: 本論文は, 京都大学防災研究所特定共同研究 「大気接地層における乱流輸送過程の観測法に関す る研究」(代表, 京都大学林泰一助教授)の研究集会 (1998年 1 月京都)の著者の講演を加筆訂正したもの であり, 同共同研究の一部である. また, そこで発 表された塚本 (1998) も一部参考にした。

浜松観測のデータは，文部省科学研究費補助金・ 基盤研究(A)「広域的適用を目指した森林の間接計測 手法開発と分散型デー夕処理手法の構築」(代表, 名古屋大学福鴧義宏教授, 課題番号07558196)において, 同研究所の福嶌教授や檜山助手たちとともに観測を 行ったものであり, 計測機は, 京都大学防災研究所 の林助教授から借用した. HEIFEのデータは, 黒 河流域における地空相互作用に関する日中共同研究 $\operatorname{HEIFE}(1991 \sim 1993)$ (代表, 京都大学, 光田寧名誉教 授)の1991年度のIOPにおいて，著者が多くの方と ともに観測したものである。全ての方々にお礼を申 し上げる。また，匿名の査読者には特に文章面で多 くの有益な意見を頂いた。

\section{参考文献}

カイマル J. C. 著, 光田 寧 - 山田道夫訳 (1993) : 微 細気象学大気境界層の構造と観測, p. 116, 技報 堂出版.

Kaimal, J. C. and Finnigan, J. J. (1994) : Atmospheric Boundary Layer Flows, p. 284, Oxford University Press.

P. Hyson and B.B. Hicks (1975): A single-beam infrared hygrometer for evaporation measurement. J. Appl. Meteor., 14, pp. 301-307.

伊藤芳樹 (1998)：シングルビーム赤外線吸収方式に よる湿度変動計測, 京都大学防災研究所共同研究 “大気接地層における乱流輸送過程の観測法に関 する研究”, pp. 23-28.

Mitsuta Y., I. Tamagawa, K. Sahashi, and J. Wang (1995) : Estimation of annual evaporation from the Linze desert during HEIFE, J. Meteorol. Soc. Japan, 73, pp. 967-974. 
Pond, S., Philips, G. T., Paquin, J. E., McBean, G., and Stewart, R. W. (1971): Measurements of the turbulent fluxes of momentum, moisture and sensible heat over the ocean. J. Atmos. Sci., 28, pp. 901-917.

清水貴範(1998)：超音波風速温度計センサー自体に よる風速遮断の補正について, 京都大学防災研究 所共同研究 “大気接地層における乱流輸送過程の 観測法に関する研究”, pp. 15-18.

J. Sun, S. K. Esbensen, and L. Mahrt(1995) : Estimation of surface heat flux, J. Atmos. Sci., 52, pp. 3162-3171.

I. Tamagawa (1996) : Turbulent characteristics and bulk transfer coefficients over the desert in the
HEIFE area, Bound. -Lay. Meteorol., 77, pp. 1-20.

O. Tsukamoto, K. Sahashi amd J. Wang (1995) : Heat budget and evapotransration at an oasis surface surrounded by desert, J. Meteorol. Soc. Japan, 73, pp. 925-935.

塚本 修(1998)：超音波風速温度計による乱流計測, 京都大学防災研究所共同研究 “大気接地層におけ る乱流輸送過程の観測法に関する研究”, pp. 114.

E. K. Webb, G.I. Pearman and R. Leuning (1980) : Correction of flux measurements for density effects due to heat and water vapour transfer, Quart. J. Roy. Meteorol. Soc., 106, pp.. 85-100.

（受付：1998年10月12日，受理：1999年 1 月 8 日） 